\title{
Violences décrites : une bibliographie très partielle
}

\section{Danielle de Lame}

\section{OpenEdition}

\section{Journals}

Édition électronique

URL : http://journals.openedition.org/apad/220

DOI : 10.4000/apad.220

ISSN : 1950-6929

\section{Éditeur}

LIT Verlag

Édition imprimée

Date de publication : 1 juin 2003

\section{Référence électronique}

Danielle de Lame, «Violences décrites : une bibliographie très partielle », Bulletin de l'APAD [En ligne],

25 | 2003, mis en ligne le 22 mars 2006, consulté le 08 septembre 2020. URL : http://

journals.openedition.org/apad/220 ; DOI : https://doi.org/10.4000/apad.220

Ce document a été généré automatiquement le 8 septembre 2020.

Bulletin de l'APAD 


\title{
Violences décrites : une bibliographie très partielle
}

\author{
Danielle de Lame
}

1 La bibliographie présentée ici a été extraite, par Madeleine Erpicum. de la base de donnée du Centre de Documentation en Sciences humaines sur l'Afrique au Sud du Sahara du Musée royal de l'Afrique centrale. Tervuren (Belgique). Elle a été mise en forme au sein de la section Anthropologie sociale et Ethnohistoire. par Knut Coekaerts.

2 La bibliographie qui suit vise à donner au lecteur un aperçu des angles d'approche de la violence dans la littérature anthropologique récemment consacrée à l'Afrique, un continent qui est loin d'en avoir l'exclusivité. Cette bibliographie est très loin de l'exhaustivité, que l'on parle des ouvrages généraux sur la violence ou des études de cas. En la compilant sur la base de données du Centre de documentation en Sciences humaines sur l'Afrique (Tervuren), sont apparus, d'une part, la diversité des domaines où les chercheurs perçoivent la violence, de la guerre et de la vie publique quotidienne à l'intimité des familles et, d'autre part, la multiplication des écrits relatifs à la violence en Afrique à partir de la fin de années quatre-vingt. La guerre civile au Liberia, qui se prolongeait, était relayée par le génocide au Rwanda, quelques années plus tard. Ces deux faits, et surtout leur durée et la gravité de leurs séquelles, font apparaitre la répression de la sécession biafraise comme une événement, certes pas bénin, mais limité dans le temps et l'espace. Les guerres civiles et les conflits armés qui les prolongent depuis une quinzaine d'années ont ceci de particulier qu'ils entraînent de larges fractions des populations civiles et enrôlent les jeunes dans des milices et des bandes armées. Celles-ci servent les pouvoirs, désormais diffractés à la mesure d'une apparente anarchie parallèle aux structures officielles, faisant perdurer la dérégulation d'une violence politique dont l'état est généralement supposé avoir le monopole.

3 Aux références présentées ci-dessous, il aurait convenu, même en nous limitant à la hase de données (30.000 titres environ) d'où elles sont extraites, ajouter 183 titres classés sous la rubrique "génocide", 217 sous la rubrique "guerre", 252 sous la rubrique "guerre civile", 40 sous la rubrique "criminalité" et 15 sous la rubrique "viol". N'oublions pas les rubriques consacrée à l'esclavage, aux conquêtes et aux pacifications 
coloniales, aux anciens royaumes africains et à leur mode de gestion du pouvoir. Un nombre important de titres relatifs à la circoncision et à l'excision aurait pu trouver leur place dans une bibliographie sur la violence. Ceci, pourtant, est matière à débat, ce qui nous pousse à nous interroger sur la relativité des normes qui régulent la violence exercée à l'égard des individus et sur la légitimité des instances qui l'exercent dans un contexte où, désormais, prévaut la pluralité des normes. La co-existence de normes internationales, de règles locales de droit écrit et de droit traditionnel crée des espaces d'incertitude. Les pouvoirs, apparemment parallèles, s'entrecroisent en réalité et bénéficient d'interstices de désordre (voir Chabal \& Dalloz 1999) dont la gestion génère des statuts prestigieux à la frange des états. Comme le montre Bayart (2004) les individus se constituent comme sujets dans l'acceptation de ces normes. Ceci nous renvoie à ces jeunes soldats terrifiants racontant, le sourire aux lèvres face à la caméra, meurtres et viols, leurs exploits récents dans les campagnes du Kivu. Ceci nous renvoie aussi à nos propres conceptions de la violence et de la légitimité de la violence, liées à des époques autant, sinon plus, qu'à des lieux. Que le lecteur se rappelle les premières pages du célèbre ouvrage de M. Foucault, "Surveiller et punir".

En ce qui concerne l'Afrique, Stephen Ellis livrera un bilan équilibré de la vision des violences liées à l'histoire de l'Afrique et à son écriture (voir son article "La violence dans l'histoire de l'Afrique" dans le catalogue de l'exposition "Mémoire du Congo" à paraître début 2005, Tervuren, Musée royal de l'Afrique centrale). Comme l'écrivait Fox (in Marsh \& Campbell $1982: 6$ ), "Pour l'homme, il y a un problème de violence... parce que l'homme attribue un sens à la violence". Ce sont ces sens qui font l'objet de l'anthropologie. La recherche se mène de l'intérieur des cultures productrices de sens sur la violence et ses modalités. Loin d'assigner une propension particulière de tel ou tel groupe à une violence qui nous choque, il s'agit d'aborder la question des sens sous-jacents à ces violences et à leur exercice. Les représentations unilatérales de la violence, ou l'absence de la violence dans les études africanistes à certaines époques, participe de visions du continent africain enchâssées dans des courants idéologiques larges. La négation et la péjoration des cultures africaines de l'époque coloniale s'y est trouvée remplacée par une vision aussi exotique qu'idyllique du continent précolonial une fois la période coloniale passée. Actuellement, il nous faut bien reconnaître la violence présente dans nos propres sociétés et, si l'opération n'est pas rassurante, elle participe pourtant de cette démarche des anthropologues qui consiste à construire leur objet de connaissance sur la brèche de l'interculturalité, et non dans la comparaison. La similitude des destins humains est le postulat sur lequel repose cette compréhension, en l'occurrence inconfortable.

\section{BIBLIOGRAPHIE}

Quelques ouvrages généraux

Abbink J., Aijmer G., 2000, Meanings of violence. Across cultural perspective, Oxford, Berg Publishers. 
Balibar E., 1996, "Violence : idéalité et cruauté", in Héritier F., De la violence, Paris, Odile Jacob : 56-87.

Bayart, J.-Fr., 2004, Le gouvernement du monde, Paris.

Chabal P., Daloz,J.P., 1999, Africa works. Disorder as political instrument, Oxford, J. Currey.

Das V., 1987, "The anthropology of violence and the speech of victims", Anthropology Today, 3, 4 : $11-13$

Dimandja Eluy'a Kondo, 1987, "Etudes sur la paix, les guerres et le violence : bibliographie sommaire", Nouvelles rationalités africaines, $2,7: 579-594$

Ellis S., 2005, "La violence dans l'histoire de l'Afrique", in Vellut J-L., La mémoire du Congo. Catalogue de l'exposition, Tervuren : Musée royal de l'Afrique centrale.

Ember M, Ember C.B., 1994 "Cross-cultural studies of war and peace : recent achievements and future possibilities", in Reyna S.P. \& Downs R.E., Studying war. Anthropological perspectives, Amsterdam, Gordon and Breach publishers : 185-208.

Héritier F., 1996, De la violence, Paris, Odile Jacob.

Krohn-Hansen C., 1994, "The anthropology of violent interaction", Journal of Anthropological Research, $5,4: 367-381$.

Lutz C., Nonini D., 1999, "The economics of violence and the violences of economies", in Moore H.L., Anthropological Theory Today, Cambridge, Polity Press : 73-113.

Marsh P., Campbell A. (réds), 1982, Agression and violence, Oxford, Oxford University Press.

Reyna S.P., Downs R.E., 1994, Studying war. Anthropological perspectives, Amsterdam, Gordon and Breach publishers. Riches D., 1986, The anthropology of violence, London, Blackwell.

Wiredu K., 1987, "La question de la violence dans la philosophie contemporaine africaine", Quest, $1,2: 30-40$.

Gestion et prévention des conflits

Adelman H., Suhrke A., 1996, Early warning and conflict management, Copenhagen, Evaluation of emergency Assistance to Rwanda.

Apodaca C., 1998, "Human rights abuses : precursor to refugee flight ?", Journal of Refugee Studies, $11,1: 80-93$

Duffield M., 1996, "The symphony of the damned : racial discourse, complex political emergencies and humanitarian aid", Disasters, 20, $3: 173-193$.

Marchal R., 1991, "Surveillance et répression en postcolonie", Politique Africaine, 42 : 40-50

Marshall T.E., 1994, "Management of violence among the Ju/wasi of Nyae Nyae : the old way and a new way", in Reyna S.P., Downs R.F., Studying war, Anthropological perspectives, Amsterdam, Gordon and Breach publishers : 69-84.

Reychler L., 1997, "Les conflits en Afrique : comment les gérer et les prévenir ? ", Conflits en Afrique. Analyse des crises et pistes pour une prévention, Bruxelles, Coédition Grip -- éditions Complexe : 15-38.

Reyna S.P., 1994, "A mode of domination approach to organized violence", in Reyna S.P., Downs R.E., Studying war. Anthropological perspectives, Amsterdam, Gordon and Breach Publishers : 29-65.

Van Brabant K., 2000, Operational security management in violent environments, London, Overseas Development Institute. 
Willett S., 1998, "Demilitarisation, disarmament and development in Southern Africa", Review of African Political Economy, 77 : 409-430.

Rebellion et résistance

Abdullah J., 1998, "Bush path to destruction : the origin and character of the revolutionary United Front/Sierra Leone", Journal of Modern African Studies, 36, 2 : 203-235.

Buijtenhuis R., 1996, "The rational rebel : how rational how rebellious ? Some African examples", Afrika Focus, 12, 1-2-3 : 3-25

Chabal P., Daloz J.P., 1999, Africa works, Disorder as political instrument, Oxford, James Currey.

Crummey D., 1996, "The great beast", in Crummey D., Banditry, rebellion and social protest in Africa, London, James Currey : 1-29.

Devisch R., 1995, "Frenzy, violence and ethical renewal in Kinshasa", Public Culture, 7, 3 : 593-629.

Doom R., Vlassenroot K., 1999, "Kony's message : a new Koine ? The Lords Resistance Army in Northern Uganda", African Affairs, 98, 391 : 5-36.

Ehrenreich R., 1998, "The stories we must tell : Ugandan children and the atrocities of the Lord's Resistance Army", Africa Today, 45,1 : 79-102.

Krikler J., 1996, "Women, violence and the Rand revolt of 1922", Journal of Southern African Studies, $22,3: 349-372$.

Mbembe A., 1991, "Désordres, résistance et productivité", Politique Africaine, 42 : 2-8.

Moore D., 1995, "Democracy, violence and identity in the Zimbabwean war of national liberation : reflections form the realms of dissent", Revue canadienne des Etudes africaines, 29, $3: 375-402$.

Nnoli O., 1987, "Revolutionary violence, development, equality and justice in South Africa", Africa Today, $24: 1-2: 27-47$.

Orkin M., 1992, "'Democracy knows no colour' : nationals for guerilla involvement among Black South Africans", .Journal of Southern African Studies, 18, 3 : 642-669.

Ranger T., 1992, "War, violence and healing in Zimbabwe", Journal of Southern African Studies, 18, $3: 698-707$.

Ranger T., 1997, "Violence variously remembered : the killing of Pieter Oberholzer in July 1964", History in Africa, $24: 273-286$.

Reyntjens F., 1995, "Akazu, 'escadrons de la mort', et autres 'réseau zéro' : un historique des résistances au changement politique depuis 1990" in Guichaoua A., Les crises politiques au Burundi et au Rwanda (1993-1994), Paris, Karthala : 265-273.

Samatar A.I., 1995, "La destruction de l'Etat et la société somalienne. Au-delà de la convention tribale", Alternatives sud, 2, $2: 153-172$.

Sapire H., 1992, "Politics and protest in shack settlements of the Pretoria-Witwatersrand-Vereeniging region, South Africa, 1980-1990", Journal of Southern African Studies, 18,3:670-697.

Sitas A., 1992, "The making of the 'Comrades' movement in Natal, 1985-91", Journal of Southern African Studies, 18, $3: 629-641$.

Sitas A., 1996, "The new tribalism : hostels and violence", Journal of Southern African Studies, 22, 2 : 235-248 
Toulabor C.M., 1996, "Jeunes, violence et démocratisation au Togo", Afrique contemporaine, 180 : 116-125.

Vlassenroot K., 2003, "Violence et constitution des milices dans l'est du Congo : Le cas des Mayi-Mayi", in Marysse S., Reyntjens F., L 'Afriques des Grands Lacs. Annuaire 2001-2002, Paris, L'Harmattan : 115-152.

Willis J., 1994, "Killing Bwana : peasant revenge and political panic in early colonial Ankole", Journal of African History, 35, $3: 379-400$.

Causes de la violence

André C., Platteau J.P., 1996, Land tenure under unendurable stress : Rwanda caught in the Malthusian trap, Namur, CRED.

Bollig M., 1996, "Kommentare zu Erwin Orywal : Krieg als Konfliktaustragungsstrategie. Zur Plausibilität on Kriegsursachentehorien aus kognitionsethnologisher", Zeitschrififur Ethnologie, $121,1: 49-53$.

Chrétien J.P., 1991, "Les racines de la violence contemporaine en Afrique", Politique Africaine, 42 : 15-27.

Connolly W.E., 1994, "Tocqueville, territory and violence", Theory, Culture and Society, 11, 1 : 19-40.

Crisp J., 2000, "A state of insecurity : the political economy of violence in kenya's refugee camps", African Affairs, 99, 397 : 601-632.

Gupta V., 1992-1993, "Violence and regionalism delay democratisation", Africa Quarterly, 32, 1-4 : 107-114.

Kent S., 1990, "Kalahari violence in perspective", American Anthropologist, 92, 4 : 1015-1017.

Kloos P., de Silva P.L., 1995, Globalization, localization and violence. An annotated bibliography, Amsterdam, VU University Press.

Knauft Br. M., 1990, "Violence among newly sedentary foragers", American Anthropologist, 92, 4 : 1013-1015.

Malkki L.H., 1995, Purity and exile : violence, memory, and national cosmology among Hutu refugees in Tanzania, Chicago, London, University of Chicago Press.

Marchal R., 2000, "Atomisation des lins et radicalisme des moyens", Critique Internationale, 6 : 159-175.

Marshall T.E., 1994, "Management of violence among the Ju/wasi of Nyae Nyae : the old way and a new day", in Reyna S.P., Downs R.E., Studying war. Anthropological perspectives, Amsterdam, Gordon and Breach Publishers : 69-84.

Mathieu P., Laurent P.J., Mafikiri T., 1997, "Compétition foncière, confusion politique et violences au Kivu : des dérives irréversibles? ", Politique Africaine, 67 : 130-136.

McGregor J., 1998, "Violence and social change in a border economy : war in the Maputo Hinterland, 1984-1992", Journal of Southern African Studies, 24, 1 : 37-60.

Orywal E., 1996, "Krieg aus Konfliktaustragunsstrategie. Zur Plausibilitat von Kriegsursachentheorien aus kognitionsethnologischer Sicht", Zeitschrift für Ethnologie, 121, 1 : $1-48$.

Pourtier R., 1998, "Les refoulés du Zaïre : identité, autochtonie et enjeux politiques", Autrepart,5 : 137-154. 
Roitman J., 1998, "La garnison-entrepôt", Autrepart, 6 : 39-51.

Shettima K.A., 1997, "Ecology, identity, developmentalism and displacement in Northern Nigeria", Journal of Asian and African Studies, 32, 1-2: 66-80.

Tsongo M., 1995, "Gestion de l'espace, manipulations politiques et violences ethniques au Kivu", in Aelvoet M., Les racines de la violence dans la région des Grands-Lacs, Bruxelles, Parlement Européen.

Uprimny R., 1996, "Le narco-trafic comme forme particulière de l'accumulation mercantile", Alternatives Sud, 3, $1: 127-140$.

Yengo P., "Un recours endémique à la violence", Afrique Contemporaine, 186 : 33-45.

Violence et Etat

Ahluwalia P., 1996, "Founding father presidencies and the rise of autoritarianism in Kenya : a case study", Africa Quarterly, 36, 4 : 45-72.

Ajayi R., 1995-1996, "The remilitarization of Nigerian politics", Africa (Sao Paulo), 18-19, 1 : 23-51.

Bangoura D., 1996, "Etat et sécurité en Afrique". Politique Africaine, n61 : 39-53.

Bayart J.Fr., 1992, "Etat et phénomène informel. Vers une criminalisation du politique", Cahiers du CEDAF, n³-4 : 219-221.

Bazenguissa-Ganga R., 1998, "Les milices politiques dans les affrontements", Afrique Contemporaine, $186: 46-57$.

Bazenguissa-Ganga R., 1998, "The political militia in Brazzaville", Issue, 26,1 : 37-40.

Bazenguissa-Ganga R., 1999, "The spread of political violence in Congo-Brazzaville", African Affairs, 98, $390:$ 37-54.

Beinart W., 1992, "Political and collective violence in Southern African historiography", Journal of Southern African Studies, 18, $3:$ 455-486.

Bertens L., 1992, "Les assassinats des dirigeants nationalistes. un moyen de confiscation de l'indépendance nationale", Congo (Zaïre) : démocratie néo-coloniale ou deuxième indépendance, Paris, L' Harmattan : 33-51.

Besteman C., 1996, "Violent politics and the politics of violence : the dissolution of the Somali nation-state", American Ethnologist, 23, 3 : 579-596.

Bierschenk Th., 1999, "Herrschaft, Verhandlung und Gewalt in einer Afrikanischen Mittelstadt (Parakou, Bénin)", Afrika Spektrum, 34, 3 :321-348.

Bradbury M., 1998, "Sudan : international responses to war in the Nuba Mountains", Review of African Political Economy, ${ }^{\circ} 77$ : 463-474.

Brett E.A., 1995, "Neutralising the use of force in Uganda : the role of the military in politics", Journal of Modern African Studies, 33, $1: 129-152$.

Bridgland F., 1995, "Savimbi et l'exercice du pouvoir : un témoignage", Politique Africaine, n57 : 94-102.

Chabal P., 1991, "Pouvoir et violence en Afrique postcoloniale", Politique Africaine, n42 : 51-64.

Charney C., 1999, "Civil society, political violence ad democratic transitions : business and the peace process in South Africa, 1990 to 1994", Comparative Studies in Society and History, 41, 1 : 182-212. 
Chrétien J.P., 1991, "Les racines de la violence contemporaine en Afrique", Politique Africaine, $n^{\circ} 42: 15-27$.

Chigono M.F., 1996, The state, violence and development. The political economy of war in Mozambique, 1975-1992, Aldershot, Avebury.

Ciekawy D., 1997, "Constitutional and legal reform in the postcolony of Kenya", Issue, 25,1 : 16-18.

Cock J., 1989, "Hidden consequences of State violence : spinal cord injuries in Soweto, South Africa", Social Science and Medicine, 29, $10: 1147-1155$.

Cooper S., 1994, "political violence in South Africa : the role of youth", Issue, 22, 2 : 27-29.

Ellis S., 1998, "The historical significance of South Africa's third force", Journal of Southern African Studies, 24, 2 : 261-299.

Falola T., 1998, Violence in Nigeria. The crisis of religious politics and secular Ideologies, Rochester, University of Rochester Press.

Gaulme F., 2000, "Côte d'Ivoire : la logique des urnes et celle de la violence", Afrique Contemporaine, 196 : 99-109.

Gilbert L., 1996, "Urban violence and health - South Africa 1995", Social Science and Medicine, 43, 5 : 873-886.

Govea R., Holm J., 1998, "Crisis, violence and political succession in Africa", Third World Quarterly, $19,1: 129-148$.

Gwala N., 1989, "Political violence and the struggle for control in Pietermaritzburg", Journal of Southern African Studies, 15, 3 : 506-524.

Hart K., 1996, "End of the world : anthropologists speechless", Anthropology Today, 7, 5 : 1-2.

Havyarimana G., 1995, "Société civile et retour à l'état au Burundi", in Verdier R., Decaux L. Chrétien J.P., Rwanda. un génocide du XXe siècle, Paris, L'Harmattan : 211-221.

Hieronymi O., 1996, "The evasion of State responsibility and the lessons from Rwanda : the need for a new concept of collective security" , Journal of Refugee Studies, 9, $3: 236-239$.

Itayavyar D.A., Ogba L.O., 1989. "Violence, conflict and health in Africa", Social Science and Medicine, 28, 7 : 649-657.

Jewkes R., Abrahams N., Mvo Z., 1998, "Why do nurses patients ? Reflection from South African obstetric services", Social Science and Medicine, 47, 11 : 1781-1795.

Kint R., 1993, Le droit pénal spécial burundais, Bujumbura, Université du Burundi. Fac. Dr..

Kloos P., de Silva P.L., 1995, Globalization, localization and violence. An annotated bibliography, Amsterdam, Vrije Universiteit.

Lanne B., 1996, "Conflits et violences au Tchad", Afrique Contemporaine, nºl80 : 52-61.

Leye E., Githaiga A., Bosmans M., Temmerman M., 2001, Male involvement in the light against violence against women, Experiences form developing countries, Ghent, University of Ghent.

Marchal R., 1991, "Surveillance et répression en postcolonie", Politique Africaine, n42, 40-50.

Mbembe A., 1988, "Etat, violence et accumulation. Leçons d'Afrique noire", Foi et développement, $\mathrm{n}^{\circ}$ $164 / 165: 1-8$.

Mbembe A., 1990, "Pouvoir, violence et accumulation", Politique Africaine, n³9 : 7-24. 
Menthong H.L., 1998, "Vote et communautarisme au Cameroun : un vote de coeur, de sang et de raison", Politique Africaine, ${ }^{\circ} 69$ : 40-52.

Moore D., 1995, "Democracy, violence and identity in the Zimbabwean war of national liberation : reflection from the realms of dissent", Revue canadienne des Etudes africaine, 29, 3 : 375-402.

Morris M., Hindson D., 1992, "South Africa : political violence, reform and reconstruction", Review of African Political Economy, n53 : 43-59.

Musambachime Mw.C., 1990, "Military violence against civilians : the case of the Congolese and Zaïrean military in the period 1890-1988", International Journal of African Historical Studies, 23, 4 : 643-664.

Nagengast C., 1994, "Violence, terror, and the crisis of the State", Annual Review of Anthropology, $23: 109-136$.

Nguema I., 1996, "Violences, droits de l'homme et développement en Afrique", Revue .Juridique et Politique, 49, $2: 121-131$.

Nhial A.A.J., Tawir Kafi N., Seisi E., 1993, "Human rights abuses in Sudan", Review of African Political Economy, n58 : 110-118.

Njue C., 2000, "Les organisation non gouvernementales et les pouvoirs publics face à la santé : l'exemple du Kenya", Afrique contemporaine, 195 : 241-249.

Prunier G., 1991, "Violence et pouvoir en Afrique", Politique Africaine, $\mathrm{n}^{\circ} 42$ : 1-14.

Oloruntimehin O., 1996, "Urban violence : health consequences and costs", Social Science and Medicine, 43, 5 : 887-888.

Rutten M., Mazrui A., Grignon F., 2001, Out for the count. The 1997 general elections and prospects for democracy in Kenya, Kampala, Fountain Puhlishers Ltd.

Thibon Chr., 1995, "Les origines historiques de la violence politique au Burundi", in Guichaoua A., Les crises politiques au Burundi et au Rwanda (1993-1994), Paris, Karthala : 55-76.

Thornton R.J., 1990, "The shooting at Uitenhage, South Africa, 1985 : the context and interpretation of violence", American Ethnologist, 17, 2 : 217-236.

Weimer B., 1995, "Mosambik hat gewählt : Analyse der Wahlergebnisse und Perspektiven des Wiederaufbaus", Afrika Spektrum, 30, $1:$ 5-33.

Wiseman J.A., 1993, "Leadership and personal danger in African politics", .Journal of Modern African Studies, 31,4: 657-660.

Violence urbaine

Abdullah L., 1998, "Bush path to destruction : the origin and character of the Revolutionary United Front/Sierra Leone", Journal of Modern African Studies, 36, 2 : 203-235.

Calas B., 1991, "La violence et ses conséquences urbaines à Kampala", Politique Africaine, $\mathrm{n}^{\circ} 42$ : 28-39.

Devisch R., 1995, "Frenzy, violence and ethical renewal in Kinshasa", Public Culture, 7, 3 : 593-629.

Diouf M., 1996, "Urban youth and Senegalese politics : Dakar 1988-1994", Public Culture, 7, 2 : 225-249.

Dordier-Apprill E., 1996, "Jeunesse et ethnicités citadines à Brazzaville", Politique Africaine, n64 : 73-88. 
Gilbert L., 1996, "Urban violence and health - South Africa 1995", Social Science and Medicine, 43, 5 : 873-886.

Kynoch G., 1999, "From the ninevites to the hard livings gang : township gangsters and urban violence in twentieth century South Africa", African Studies, 57, 1 : 55-85.

Lecompte D., 1996, "Une ville africaine dans la tourmente, la guerre à Bujumbura", Afrique Contemporaine, $\mathrm{n}^{\circ} 180,160-172$.

Marchal R., 1993, "Les 'mooryaan' de Mogadiscio. Formes de la violence dans un espace urbain en guerre", Cahiers d'Etudes Africaines, 33, 2, n $130: 295-320$.

Oloruntimehin O., 1996, "Urban violence : health consequences and costs", Social Science and Medicine, 43,5: 887-888.

Ossebi H., 1998, "De la galère à la guerre : jeunes et 'Cobras' dans les quartiers nord de Brazzaville", Politique Africaine, ${ }^{\circ} 72: 17-33$.

Paulenz S., 1999, "Selbstjustiz in Benin. Zur Debatte über den Cahrakter Ausserstaatlicher Sanktionsformen in Afrika", Afrika Spektrum, 34, 1 :59-83.

Ramphele M.A., 1997, "Adolescents and violence : 'Adults are cruel, they just beat, beat, beat !' ", Social Science and Medicine, 45, $8: 1189-1197$.

Rodriguez-Torres D., 2000, "A chacun son trottoir : l'appropriation des espaces publics par les jeunes de Nairobi", in Grignon F., Maupeu H., L'Afrique orientale. Annuaire 2000, Paris, L'Harmattan : 225-349.

Sapire H., 1992, "Politics and protest in shack settlements of the Pretoria-Witwatersrand-Vereeniging region, South Africa, 1980-1990", Journal of Southern African Studies, 18,3:670-697.

Scheper-Hughes N., 1994, "The last white Christmas : the Heidelberg pub massacre", American Anthropologist, 96, $4:$ : 805-817.

Scheper-Hughes N., 1996, "Small wars and invisible genocides", Social Science and Medicine, 43, 5 : 889-900.

Segal L., 1992, "The human face of violence : hostel dwellers speak", Journal of Southern African Studies, 18, $1:$ 190-231.

Violence Domestique

Campbell C, 1992, "Learning to kill ? Masculinity, the family and violence in Natal", Journal of Southern African Studies, 18, $3:$ 614-628.

Carillo R., Tello J., 1998, Family violence and men of color, New York, Springer.

Dez J., 1981, "L'illusion de la non-violence dans la société traditionnelle malgache", Droit et Culture, $n^{\circ} 2: 21-44$.

Erchak G.M., 1984, "Cultural anthropology and spouse abuse", Current Anthropology, 25, 3 : 331-332.

Geschiere P., Fisiy C., 1994, "Domesticating personal violence : witchcraft, courts and confessions in Cameroun", Africa, 64.3 :323-341.

Ramphele M.A., 1997, "Adolescents and violence : 'Adults are cruel they just beat, beat, beat !'", Social Science and Medicine, 45, $8: 1189-1197$. 
Wagner U., 1990, "Child training practices and violent conflict management", Zeitschrift für Ethnologie, $115: 67-72$.

Violence au quotidien

Dodge C.P., Raundalen M., 1987, War, violence. and children in Uganda, Oslo, Norwegian University Press.

Dordier-Apprill E., 1996, "Jeunesse et ethnicités citadines à Brazzaville", Politique Africaine, n64 : 73-88.

Ellis S., 1994, "Mbokodo : security in ANC camps, 1961-1990", African Affairs, 93, n³71 : 279-298. Irung Tshitambal's Mulang, 1987, "Paix et visage de la violence sociale", Nouvelles Rationalités Africaines, $2, \mathrm{n}^{\circ} 9: 503-508$.

Jok J.M., 1999, "Militarization and gender violence in South Soudan", Journal of Asian and African Studies, 34, 4 : 427-442.

Killingray D., "The 'Rod of Empire' : the debate over corporal punishment in the British African Colonial Forces, 1888-1946", Journal of African History. 35, 2 : 201-216.

Maake N,P., 1992, "Multi-cultural relations in a post-apartheid South Africa", African Affair, 91. $\mathrm{n}^{\circ} 365: 583-604$.

Ondicho T.G., 2000, "Battered women : a socio-legal perspectives of their experiences in Nairobi", African Study Monographs, $21, \mathrm{n}^{\circ} 1: 35-44$.

Scheper-Hughes N., 1996, "Small wars and invisible genocides", Social Science and Medicine, 43, 5 : 889-900.

Segal L., 1992, "The human face of violence : hostel dwellers speak", Journal of Southern African Studies, $18,1: 190-231$.

\section{Genre et Violence}

1996, Shattered lives. Sexual violence during the Rwandan genocide and its aftermath, New York, London. Bruxelles, Human Rights Watch.

Ampofo A.A., 1993, "Controlling and punishing women : violence against Ghanaian women", Review of African Political Economy, ${ }^{\circ} 56$ : 102-111.

Bloch M., 1996, "La 'consommation' des jeunes hommes chez les Zafimaniry de Madagascar", in Héritier F., De la violence, Paris, Odile Jacob : 201-222.

Campbell C., 1992, "Learning to kill ? Masculinity, the family and violence in Natal", Journal of Southern African Studies, 18, $3: 614-628$.

Carillo R., Tello J., 1998, Family violence and men of color, New York. Springer.

Dauphin C., Farge A., 1997, De la violence et des fèmmes, Paris, Pocket.

Engle Merry S., 2001, "Changing rights. changing culture", in Cowan J.K., Dembour M.B., Wilson R.A., Culture and Rights, Cambridge, Cambridge University Press : 31-55.

Erchak G.M., Rosenfeld R., 1994, "Societal isolation. violent norms, and gender relations : a reexamination and extension of Levinson's model of wife beating", Cross-Cultural Research, 28. 2 : 111-133.

Hutchinson S.E., Jok J.M., 2002, "Gendered violence and the militarisation of ethnicity. A case study from South Sudan", in Werbner R., Postcolonial subjectivities in Africa, London, Zed Books : 84-107. 
Jok J.M., 1999, "Militarism. gender and reproductive suffering : the case of abortion in Western Dinka", Africa, 69, 2 : 194-212.

Jok J.M., 1999, "Militarization and gender violence in South Soudan", Journal of Asian and African Studies, 34, $4:$ 427-442.

Krais B., 1993, "Gender and symbolic violence : female oppression in the light of Pierre Bourdieu's theory of social practice", in Calhoun C., LiPuma E., Postone M., Bourdieu : Critical Perspectives, Cambridge, Polity Press : 156-177.

Krikler J., 1996, "Women, violence and the Rand revolt of 1922", Journal of Southern African Studies, $22,3: 349-372$.

Leye E., Githaiga A., Bosmans M., Temmerman M., 2001, Male involvement in the fight against violence against women. Experiences form developing countries, Ghent, University of Ghent.

1995, Not so innocent. When women become killers, London, African Rights.

Aspect culturel de la violence

Abbink J., 2000, "Restoring the balance. Violence and culture among the Suri of southern Ethiopia", Abbink J., Aijmer G., Meaning of violence. Across cultural perspective, Oxford, Berg publishers : 77-100.

Argenti N., 1998, "Air youth : performance. violence and the state in Cameroon", Journal of the Royal Anthropological Institute, 4,4 : 753-781.

Ashforth A., 1998, "Reflections on spiritual insecurity in a modern African city (Soweto)", African Studies Review, 41, $3:$ 39-67.

Beaujard P., 1995, "La violence dans les sociétés du sud-est de Madagascar", Cahiers d'Etudes Africaines, 35, 2-3 : 563-598.

Bloch M., 1996, "La 'consommation' des jeunes hommes chez les Zalimaniry de Madagascar", in Héritier F., De la Violence, Paris, Odile Jacob : 201-222.

Campbell C., 1992, "Learning to kill ? Masculinity, the family and violence in Natal", Journal of Southern African Studies, 18, $3:$ 614-628.

Copet-Rougier E., 1986, "'Le mal court' : visible and invisible violence in an acephalous society Mkako of Cameroon", in Riches D., The Anthropology of Violence, London, Blackwell : 50-69.

de Lame D., 1997, "Le génocide rwandais et le vaste monde, les liens du sang", in F. Reyntjens \& S. Marysse, L'Afrique des Grands-Lacs, 1996-1997, Paris : L'Harmattan : 157-177.

de Lame D., 2004, "Mighty Secrets, Public Commensality and the Crisis of Transparency. Rwanda through the Looking Glass", Canadian Journal of African Studies, 38, 3.

Dez J., 1981, "L'illusion de la non-violence dans la société traditionnelle malgache", Droit et Culture, $\mathrm{n}^{\circ} 2: 21-44$.

Ellis S., 1999, "The Mask of Anarchy. The Destruction of Liberia and the Religious Dimension of an African Civil War", New York, New York University Press.

Falola T., 1998, Violence in Nigeria. The crisis of religious politics and secular ideologies, Rochester, University of Rochester Press.

Geschiere P., Fisiy C., 1994, "Domesticating personal violence : witchcraft, courts and confessions in Cameroun", Africa, 64, 3 : 323-341. 
Heald S., 1986, "The ritual use of violence : circumcision among the Gisu of Kenya", in Riches D., The Anthropology of Violence, London, Blackwell : 70-85.

Héritier F., 1996, "Réflexions pour nourrir la réflexion", in Héritier F., De la violence, Paris, Odile Jacob : 11-53.

Linger D.T., 1992, Dangerous encounters. Meanings of violence in a Brazilian City, Stanford (California), Stanford University Press.

Mohr M., 1991, "'Walking the political tightrope'. Zionist responses to a climate of violence", Africana Marburgensia, 24, $1:$ 47-60.

Parkin D., 1986, "Violence and will", in Riches D., The Anthropology of Violence, London, Blackwell : 204-223.

Poewe K, 1993, "Theologies of black South Africans and the rhetoric of peace versus violence", Canadian Journal of African Studies, 27, $1:$ 43-65.

Prunier G., 1997, "Segmentarité et violence dans l'espace somali, 1840-1992", Cahiers d'Études Africaines, 37, 2 : 379-401.

Richards P., 1998, "Sur la nouvelle violence politique en Afrique : le sectarisme séculier au Sierra Leone", Politique Africaine, $\mathrm{n}^{\circ} 70$ : 85-104.

Simonse S., 1992, Kings of disaster. Dualism, centralism and the scapegoat king in South eastern Sudan, Leiden, New York, Köln, E..J. Brill.

Sommer H., 1996, "From apartheid to democracy : patterns of violent and non-violent direct action in South Africa, 1984-1994", Africa Today, 43, 1: 53-76.

Uchendu V.C., 1975, "The cultural root of aggressive behavior in modern African politics", Journal of Asian and African Studies, 12, 1-4 : 99-108.

Welsh D., 1995, "Transition by consensus", Africa Quarterly, 35, $3:$ 33-42.

Williams P.A.T., 1997, "Religion, violence and displacement in Nigeria", Journal of Asian and African Studies, 32, 1-2 : 33-49.

Wilson K.B., 1992, "Cults of violence and counter-violence in Mozambique", Journal of Southern African Studies, 18,3: 527-582.

Zitelmann Th., 1993, "Violence, pouvoir symbolique et mode de représentation des Oromo", Politique Africaine, $\mathrm{n}^{\circ} 50$ : 45-58.

Violence ethnique

Adam H., Moodley K., 1992, "political violence. 'tribalism'. and Inkatha", Journal of Modern African Studies, 30, $3: 185-510$.

Apodaca C., 1998, "Human rights abuses : precursor to refugee flight ?", Journal of Refugee Studies, 11. $1: 80-93$

Apparudai A., 1998, "Dead certainty : ethnic violence in the era of globalization", Public Culture, $10,2: 225-247$.

Bollig M., 1993, "Intra- and interethnic conflict in Northwest Kenya", Anthropos, 88, 1-3 : 176-184.

Chrétien J.P., 1991, "Les racines de la violence contemporaine en Afrique", Politique Africaine, 42 : 15-27.

Connolly W.E., 1994, "Tocqueville, territory and violence", Theory, Culture and Society, 11, 1 : 19-40. 
Dordier-Apprill E., 1996, "Jeunesse et ethnicités citadines à Brazzaville", Politique Africaine, n64 : 73-88.

Ellis S., 1995, "Liberia 1989-1994 : a study of ethnic and spiritual violence", African Affairs, 94, 375 : 165-197.

Hardin R., 1995, "Self interest, group identification". in Comaroff J.L., Stern P.C., Perspectives on nationalism and war. Amsterdam, Gordon and Breach publishers : 15-45.

Hart K., 1996, "End of the world : anthropologists speechless", Anthropology Today, 7,5 : 1-2.

Hutchinson S.E., Jok J.M., 2002, "Gendered violence and the militarisation of ethnicity. A case study from South Sudan". in Werbner R., Postcolonial subjectivities in Africa. London, Zed Books : 84-107

Jenkins R., 1997, Rethinking ethnicity. Arguments and explorations, London, Thousand Oaks, Sage Publications.

Kloos P., de Silva P.L., 1995, Globalization. localization and violence. An annotated bibliography, Amsterdam, Vrije Universiteit.

Lambert M., 1998, "Violence and the war of words : ethnicity versus nationalism in the Casamance", Africa, 67, $4: 585-602$.

Lecompte D., 1996, "Une ville africaine dans la tourmente, la guerre à Bujumbura", Afrique contemporaine, $\mathrm{n}^{\circ} 180,160-172$.

Malkki L.H., 1995, Purity and exile : violence, memory. and national cosmology among Hutu refugees in Tanzania, Chicago, London, University of Chicago Press.

Nahoum-Grappe V., 1996, "L'usage politique de la cruauté : l'épuration ethnique (1991-1995)",. in Héritier F., De la violence, Paris, Odile Jacob : 273-323.

Rutten M., Mazrui A., Grignon F., 2001, Out for the count. The 1997 general elections and prospects for democracy in Kenya, Kampala, Fountain publishers.

Thibon Chr., 1995, "Les origines historiques de la violence politique au Burundi", in Guichaoua A., Les crises politiques au Burundi et au Rwanda (1993-1994), Paris, Karthala : 55-76.

Tsongo M., 1995, "Gestion de l'espace. manipulations politiques et violences ethniques au Kivu", Aelvoet M., Les racines de la violence dans la région des Grands-Lacs, Bruxelles, Parlement Européen.

Vidal C., 1995, "Les politiques de la haine", Les Temps Modernes, n583 : 6 - 33.

\section{AUTEUR}

\section{DANIELLE DE LAME}

Anthropologie Sociale / Ethnosociologie et Ethnohistoire- Chef de section, Musée royal de l'Afrique centrale de Tervuren; danielle.de.lame@africamuseum.be 